\title{
Flying Geese of Japan: Asian Electronic Industry
}

Norimah $\mathbf{R}^{1 *}$, Dayang-Affizah $\mathrm{AM}^{2}$, Mee-Sing $\mathrm{T}^{2}$ and Kai-Lynn $\mathrm{K}^{2}$

${ }^{1}$ Department of Economics, Faculty of Management and Economics, Sultan Idris Education University, Malaysia

${ }^{2}$ Department of Economics, Faculty of Economics and Business, University Malaysia Sarawak, Malaysia

\begin{abstract}
Although Japan is known as the largest electronics goods manufacturer, many Japanese companies are facing high cost production due to limited resources. Some Asian countries have been proven to surpass Japan due to their low cost production and cheaper labour. This study analyse the development of Asian leading electronic industries and validity Japan as the flying geese in Asian electronic industries. The empirical result shows that all Asian countries are divergence except Italy, India, United Kingdom and Indonesia. The study suggest that each of the Asian convergence countries should cooperate, give their obligation and commitment to track in the same direction of economic structure, political will and the income distribution of a country. This action could promote economic integration between Asian countries as a whole.
\end{abstract}

\section{Keywords: Convergence; Economic growth; GDP}

\section{Introduction}

Manufacturing sector plays a vital role in contributing to the economy. It has created massive job opportunity as well as raised the standard of living for developed and also developing countries including China, India, South Korea, Mexico, and Brazil. Manufacturing industry can be classified into few categories which are engineering, textile, construction, electronics, chemical, energy, food and beverage, plastic, transport and telecommunication. According to McKinsey [1] global institute, manufacturing industry has contributed nearly $16 \%$ of global GDP and created a total of 62 million of opportunity job in advanced economies in the year 2000. The manufacturing sector is also known as the top multiplier effect to the economy because it will bring additional value of $\$ 1.40$ for every $\$ 1$ spends in the manufacturing industry.

Technically, value-added manufacturing is the product of the number of workers multiplied by productivity (value-added per person). Japan has become a well-known exporting country with the capability to produce highly competitive electronic goods. Government of Japan displays their support by implementing various policies and strategies relating to export and manufacturing especially electronic production, hoping to boost this industry. The authorities provided fund and assistance in the research and development activities to aid these electronic industries become more competitive. For instance, after the financial crisis which is in the year 2010, the authorities had implemented subsidies for automobile and other electronic components and devices. As a result, Japanese electronics industry production had reached $¥ 15.3$ trillion and $¥ 15.7$ trillion respectively in 2010, 2011.

Japan is considered to own the absolute advantages in producing high-tech and precision products such as such as optical instruments, hybrid vehicles, and robotics. According to Economy Watch [2], electronic industry in Japan is known as the largest electronics goods manufacturer and world's third largest automobile manufacturer. The most famous Japanese electronics companies in the world are Sony and Panasonic. However, as this country seems to excel any other countries in this aspect, it also has its hardship that needed to be encountered. Many Japanese companies have to outsource their electronic products by purchasing low cost component goods from another company and shift part of the operation business to overseas. Not only that, Japanese companies are facing the obstacles to compete against lower price rivals from Asian country such as South Korea and Taiwan. Asian rivals prefer to set up their plant in country India, Thailand, and Indonesia because it has cheaper land and labor cost is very low. This enables them to produce high quality and lowest price of electronic devices to consumers. Therefore, if this situation persists, South Korea and Taiwan might become the new dominant in the market of electronic industry. As such, this study is to validity Japan as the flying geese in Asian electronic industries.

\section{Literature Review}

There has been extensive theoretical and empirical research on contribution of high-technology industry to economic growth in both developed and developing countries. For example, Sun et al. [3], Connolly et al. [4] have conducted a research on the relationship between high-tech capital investment and productivity by using variable output (value added), capital stock, labor. Sun et al. [3] found out that technological progress and technical efficiency were the major contribution to the total factor productivity (TFP) growth in the Korean manufacturing. Connolly et al. [4] on the other hand discovered three alternative ways to stimulate an increase in the production of high technology industry which are increasing multi-factor productivity (MFP) in the production process, capital accumulation, and improving the infrastructure.

Niininen [5] the main purpose is to investigate information technology and economic growth in Finland by using the neoclassical growth. The result indicated that the income share of capital in Finland has contributed nearly 28 percent to the net output growth. Moreover, Bregman et al. [6] demonstrated a research paper on contribution of high tech to productivity in Israeli by using method Cobb-Douglas and Trans log production function to examine the 670 of establishment companies in the year 1982. The finding implied that high tech firms

*Corresponding author: Norimah R, Department of Economics, Faculty of Management and Economics, Sultan Idris Education University, Tanjong Malim, Perak, Malaysia, Tel: +015-48117449; E-mail: norimah@fpe.upsi.edu.my

Received March 11, 2016; Accepted May 24, 2016; Published May 27, 2016

Citation: Norimah R, Dayang-Affizah AM, Mee-Sing T, Kai-Lynn K (2016) Flying Geese of Japan: Asian Electronic Industry. J Glob Econ 4: 191. doi:10.4172/23754389.1000191

Copyright: ( 2016 Norimah R, et al. This is an open-access article distributed under the terms of the Creative Commons Attribution License, which permits unrestricted use, distribution, and reproduction in any medium, provided the original author and source are credited. 